\title{
A poesia no arquivo da anistia
}

Resumo: No final da década de 1970, a poesia foi usada como estratégia privilegiada para disseminar o ideário da luta pela anistia no Brasil, servindo como meio de didatização e propagação dos seus motes e como forma de denúncia, testemunho e rememoração. Após a sanção da lei da anistia, os ex-presos escreveram e publicaram um conjunto de livros, formando um quadro literário específico. Este artigo descreve as principais tendências da poesia circunstanciada a essa condição de produção.

Palavras-chave: análise do discurso, arquivo, Comitê Brasileiro pela Anistia (CBA), poesia brasileira

Abstract: In the late 1970s, poetry was used as a privileged strategy to disseminate the ideas of the social movement, serving as a form of didactic material or propaganda pro-amnesty slogan and as a form of denunciation, testimony, and remembrance. After the amnesty law, the amnestied militants wrote and published a set of books, forming specific literature. This work describes the main trends in poetry circumscribed to this condition of production.

Keywords: discourse analysis, archive, Brazilian Committee of Amnesty, Brazilian poetry

\author{
"Viajo consultando arquivos \\ e a memória ilumina rostos \\ redivivos." \\ (Lara de Lemos. Inventário do medo [1997])
}

Em abril de 2021, iniciamos um projeto de pesquisa sobre a relação entre poesia e acontecimento no arquivo da anistia. O objetivo da pesquisa é reunir, descrever, interpretar e divulgar a poesia diretamente ligada à primeira fase da luta pela anistia no Brasil, organizada no final da década de 1970, principalmente em torno do Comitê Brasileiro pela Anistia (CBA). ${ }^{1}$

A partir do quadro teórico-metodológico da análise do discurso desenvolvida por Michel Pêcheux e seus leitores, um conjunto de poemas será selecionado por meio de um trabalho de pesquisa no fundo documental do CBA e de outros materiais a ele associados, como acervos digitais, folhetos e livros de poesia. Vale destacar que o campo 
de documentos aqui designado como "arquivo da anistia" não se restringe ao fundo documental do CBA, da mesma forma que "arquivos da ditadura" concernem a um campo mais abrangente do que os documentos dos órgãos de informação e repressão, como as Forças Armadas e as instituições policiais. Com o intuito de complementar o trabalho de compilação dessa produção poética, consultamos outros fundos, disponíveis no acervo digital do Memorial da Anistia e no Centro de Referência Virtual do Armazém da Memória.

Ao lado desses campos documentais, a Hemeroteca Digital da Biblioteca Nacional é um valioso instrumento de pesquisa, na medida em que muitos poemas ligados ao contexto da anistia só circularam na imprensa de resistência à ditadura civil-militar brasileira (Ribeiro 2020a), a exemplo do suplemento da Tribuna da Imprensa, que, em 1979, publicou uma série de textos ligados à luta em prol da libertação dos presos políticos (fig. 1).
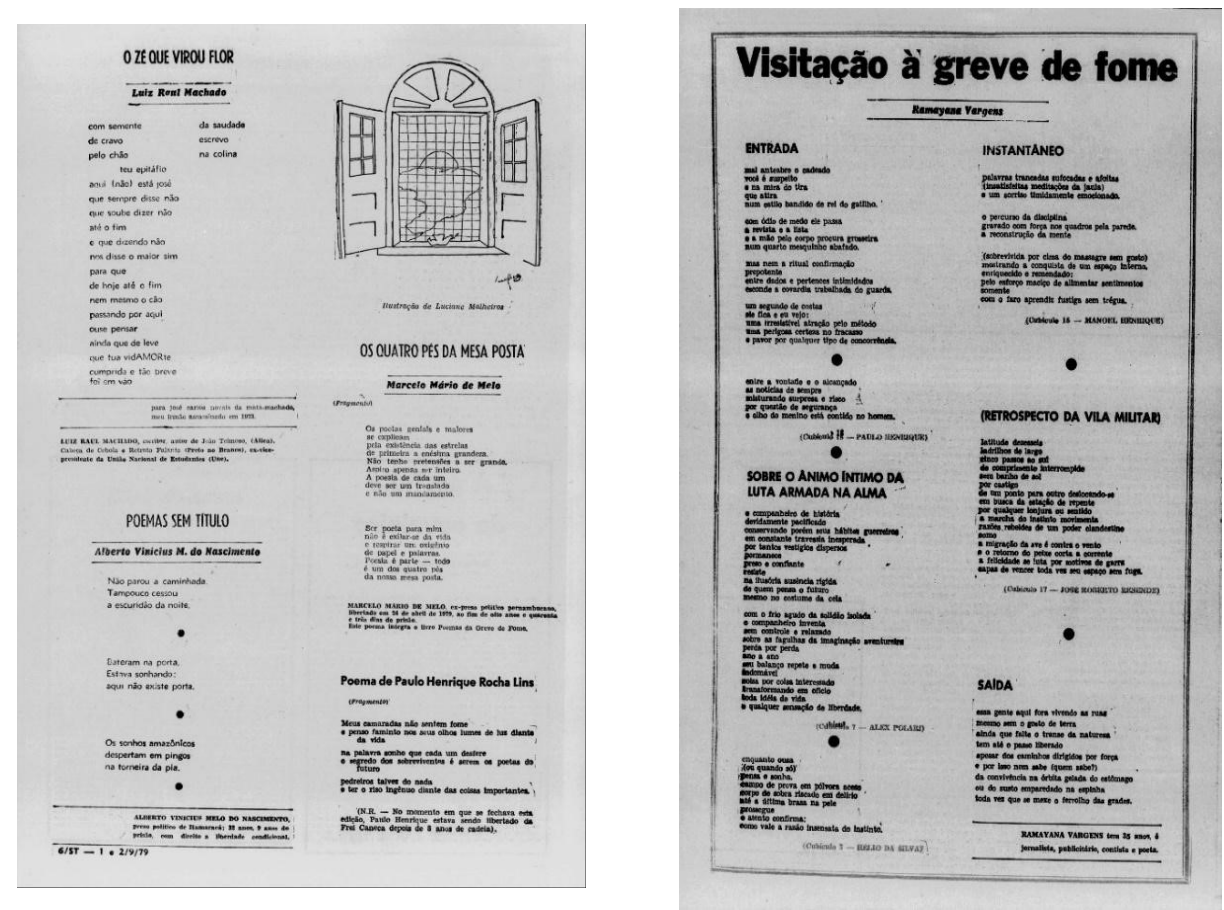

Fig. 1 - Suplemento da Tribuna da Imprensa, 1 e 2 de setembro de 1979 (páginas 18 e 20). Disponível em: <http://memoria.bn.br/DocReader/154083_03/36596>. Acesso 9 set. 2021.

Face a tal proposta, o presente artigo visa descrever o processo de construção de nosso corpus, demarcando as principais tendências da poesia circunstanciada a essa condição de produção e, mais especificamente, a esse arquivo de leitura. 


\section{Um retorno aos arquivos da ditadura}

A partir do historiador Henry Rousso, Eurídice Figueiredo oferece uma entrada possível para apreendemos o conceito de arquivo num sentido amplo, elencando quatro vetores que se combinam no constante trabalho de desconstrução/reconstrução de um acontecimento histórico: a) os vetores oficiais (comemorações, monumentos, celebrações promovidos pelo Estado); b) os vetores associativos (associações e grupos formados por membros da sociedade); c) os vetores culturais (cinema, literatura, artes plásticas, televisão etc.); e d) os vetores científicos (produção de livros de história e manuais escolares). Ainda que essa divisão esteja sujeita a falhas, ela aponta para o fato de que os "arquivos da ditadura" são uma construção móvel, historicamente determinada e sensível às transformações político-sociais.

Para tratar dos arquivos da ditadura, é imprescindível se referir a três momentos que foram fundamentais tanto para a apuração das graves violações aos direitos humanos quanto para o arquivamento dos documentos que comprovavam as acusações. No vetor associativo, por iniciativa da sociedade civil, houve o trabalho feito pelo grupo "Brasil: nunca mais", e no vetor oficial, por ação governamental, a Comissão Especial sobre Mortos e Desaparecidos [1995] e a Comissão Nacional da Verdade [2011]. (Figueiredo 2017: 15)

Próximo ao momento histórico por nós contemplado, o projeto "Brasil: nunca mais" (BNM) foi coordenado por Dom Paulo Evaristo Arns, cardeal da Arquidiocese de São Paulo, e pelo pastor presbiteriano Paulo Wright, familiar de desaparecido político. Realizado entre 1979 e 1985, o BNM congregou advogados, religiosos e jornalistas buscando cumprir três grandes objetivos: "evitar que os processos judiciais por crimes políticos fossem destruídos com o fim da ditadura militar, tal como ocorreu ao final do Estado Novo; obter e divulgar informações sobre torturas praticadas pela repressão política; e estimular a educação em direitos humanos” (BNM DIGIT@L, 2016, n.p.). O grupo fotocopiou processos de tribunais militares, aproveitando o tempo que os advogados tinham para examiná-los. Os documentos oficiais eram então usados para comprovar a existência da prática reiterada e institucionalizada da tortura, utilizada pelo regime como ferramenta de investigação e repressão. O livro-reportagem do BNM, por sua vez, sintetizou e difundiu os resultados dessa extensa investigação nos processos judiciais da repressão, chegando à surpreendente marca de 40 edições. Para Eurídice Figueiredo (idem: 16), o trabalho de arquivamento, feito clandestinamente e com o apoio do Conselho Mundial das Igrejas, teve um impacto crucial "para se começar a escrever a história das torturas no período".

Ao lado do Projeto BNM, há um outro campo documental, talvez menos conhecido, mas igualmente constituído nessa conjuntura. Trata-se dos fundos ligados ao CBA e àquilo que designamos genericamente como o "arquivo da anistia". 
Durante a década de 1970, a reivindicação da anistia em prol de perseguidos políticos foi gradualmente integrada ao programa de entidades, organizações e partidos de oposição à ditadura civil-militar. 0 engajamento de diversos grupos pró-direitos humanos resultou em uma das maiores mobilizações sociais da nossa história, sobretudo no período de transição entre os governos de Ernesto Geisel e João Figueiredo.

Nesse momento, a reivindicação da anistia para presos e perseguidos políticos, para cidadãos cujos direitos políticos haviam sido cassados e para os banidos e os exilados, marca e cristaliza o ponto de inflexão em que importantes setores da esquerda brasileira passam a apresentar, como principal bandeira, a defesa das "liberdades democráticas", deixando em segundo plano outras propostas mais radicais de transformação política e social. (Maués 2011: 258)

Sob influência do Movimento Feminino pela Anistia (MFPA), ${ }^{2}$ o primeiro CBA foi fundado em fevereiro de 1978, com sede no Rio de Janeiro. Nos meses seguintes, surgiram outros núcleos regionais (estaduais e municipais) até que, em novembro, ocorreu o I Congresso Nacional pela Anistia. Embora cada núcleo apresentasse questões específicas, o objetivo comum era reconquistar as liberdades democráticas perdidas após o golpe militar (1964) e o Al-5 (1968). Afetado pela revolta coletiva contra a censura e a repressão, o movimento operava com diversas demandas, como o fim dos processos políticos e da Lei de Segurança Nacional, a denúncia e apuração das violações de direitos humanos e o direito à livre organização partidária e sindical. Seu programa aparecia no slogan "anistia ampla, geral e irrestrita", contraposto à "distensão lenta, gradual e segura" e às "promessas de abertura e de mão estendida em conciliação", propostas por Geisel e Figueiredo.

Tanto a disseminação do lema do CBA quanto o aparecimento de uma nova "significação" de anistia podem remeter à noção de acontecimento discursivo. Grosso modo, o acontecimento desestrutura/reestrutura uma rede de filiações sócio-históricas já-dadas. Sustentado por um conjunto de formulações anteriores (retomadas, deslocadas, invertidas do campo político), um elemento inaudito irrompe "no ponto de encontro de uma memória e de uma atualidade" (Pêcheux 2012: 16). Isso faz com que certos efeitos de sentido sejam inseridos numa rede de relações associativas, como alusões, paráfrases, implicações e comentários. Um exemplo de acontecimento discursivo no período da abertura é a própria possibilidade de substituição entre os termos "anistia" e "liberdade".

Michel Pêcheux (2011a) argumenta que a liberdade é um objeto paradoxal, estruturado segundo relações de forças heterogêneas e historicamente dadas. Mais do que equivaler a "significação política" de anistia à de liberdade, nosso aporte teóricometodológico permite indagar as múltiplas formas de inscrição da materialidade da língua na discursividade do arquivo (Pêcheux 2010). Assim, podemos nos ater, por exemplo, às variações léxico-sintáticas (como o par liberdade/libertação) e a outras determinações postas em jogo, como ocorre nas seguintes sequências: "não queremos 
liberdade pela metade!”; "poemas do cárcere e da liberdade”; “... na luta por liberdades democráticas"; e "ampla campanha pela libertação dos presos políticos". Um exemplo do jogo entre anistia e liberdade também se dá no interior dos poemas associadas à campanha pela anistia, como pode ser lido no penúltimo verso de um escrito de Maria Cristina Ferreira de Oliveira, ex-presa política que, na época, cumpria pena de 12 anos na Penitenciária Talavera Bruce (RJ). ${ }^{3}$

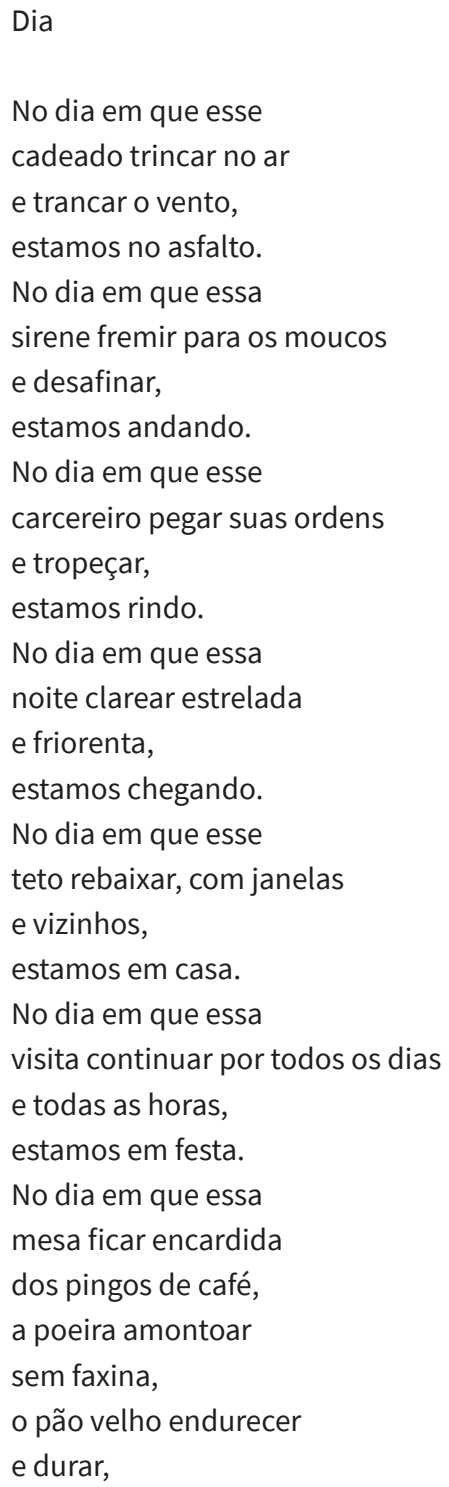


os filhos exercitam a presença com seus pais os pais exercitam a presença com seus filhos.

Corremos todos para

a mesma mesa clareira de sol, mesmo que chova, sentimos todos o mesmo calor, mesmo que inverno, cantamos todos a mesma canção, mesmo com lágrimas.

Companheiros desaparecidos, rostos não esquecidos, na linha circular indefinida vozes ressoam.

Companheiros mortos deixam fincados os marcos da luta, nenhum morreu totalmente, seus nomes renascem com nossos filhos.

Nenhum morreu

por conta própria, foi na tortura que te transformaram em vice-morto de futuro morto. Companheiros exilados saudades, certeza do retorno. Companheiros banidos, varridos de nossa terra, a maior espera.

Dia de cadeados trincados - Anistia! Dia de certezas no horizonte - Anistia! Dia de flores novas nos cemitérios - Anistia! Dia de emoções nos reencontros - Anistia! Dia de liberdade construída - Anistia!

Dia de Anistia! - Anistia! - Anistia! (CBA, s.d. [PASTA 042]: 222; grifo nosso) 
Não pretendemos analisar os aspectos formais, temáticos e composicionais desse poema datilografado e disponibilizado nos fundos do CBA. Convém destacar apenas que o escrito gira em torno de problemáticas cruciais da luta pela anistia, a começar pelo tom prospectivo (embora não utópico) e pela proliferação de imagens relacionadas à libertação, desde os primeiros versos: "no dia em que esse/cadeado trincar no ar". Há ainda uma espécie de balanço das perdas produzidas pela repressão, elaborado em torno da figura dos companheiros (desaparecidos, mortos sob tortura, exilados e banidos). Por fim, a conclusão reitera oito vezes a palavra de ordem, sempre exclamativa. No penúltimo verso, a expressão "dia de liberdade construída" é marcadamente relacionada ao termo "Anistia!", endossando tal associação metafórica dada antes, alhures e independentemente. Aliás, a própria repetição da palavra "dia" faz ecoar, já no título, o encontro vocálico da palavra "anistia", como ocorre também em outros poemas do arquivo, como o "Projeto bucaneiro para o dia da anistia", de Alex Polari (1978: 46): "Sem lar nem profissão/no Dia da Anistia/farei vestibular para pirata".

Devido à mobilização popular, o Estado foi pressionado a atender a certas demandas, como a libertação dos presos políticos e o retorno dos exilados, mas isso só ocorreu por meio da imposição jurídica de uma anistia "bilateral", parcial e restrita, conforme convinha aos militares. Para evitar uma abordagem anacrônica das tensões e das contradições textualizadas em nosso material, é necessário diferenciar a campanha pela "anistia ampla, geral e irrestrita" da lei da anistia redigida e sancionada pelos próprios agentes do Estado em agosto de 1979. Ao se apropriar da palavra enunciada pela oposição e inverter o seu valor, segundo um "funcionamento cínico da ideologia" (Di Nizzo 2019), tal política de esquecimento suscitou um "efeito de consenso" na memória, encobrindo a discrepância entre a anistia demandada pelo corpo social e a ofertada pelo Estado (Indursky 2014).

Extinto em 1985, o CBA nos legou um campo de documentos sobre esse momento particular de nossa formação social. Parte significativa do acervo foi reunida em um fundo de natureza institucional e disponibilizada para livre consulta no Centro de Pesquisa e Documentação Social do Arquivo Edgard Leueronth (AEL-UNICAMP).

[O fundo] registra uma das mais importantes atuações da sociedade civil contra a violência aos presos políticos brasileiros, no final da década de 1970, em pleno período de ditadura militar. Os documentos são relativos às atividades administrativas da entidade e de alguns de seus núcleos estaduais e municipais, atividades de divulgação relativa aos presos políticos - biografias, depoimentos, registros das famílias, histórico da repressão e regime carcerário. Contém: correspondência, manuscritos de anotações, endereços e informações sobre presos políticos, documentos administrativos, cartazes, textos, panfletos, periódicos e documentos de divulgação de eventos realizados com a finalidade de divulgar a violência política e propagar os direitos humanos. (AEL Digit@l, s.d.: 32) 
Segundo os instrumentos de pesquisa do AEL, o fundo possui 2 metros lineares de documentação textual, distribuída em 70 pastas. Doado em 1990 pelo núcleo do Rio de Janeiro, esses documentos foram organizados com apoio da Fapesp em 1991 e revisados em 2014 pela seção de Processamento Técnico, sendo integralmente digitalizado a pedido da Comissão Nacional da Verdade. Os documentos datam de 1978 a 1985 e estão distribuídos em quatro séries, cada qual dividida em subséries, itens e subitens. A primeira série ("produção") reúne os escritos redigidos e assinados pelo próprio CBA desde seu primeiro ano de existência. Entre eles, encontram-se vários tipos de documentos, de natureza e objetivo heterogêneos, como panfletos, folhetos, cartões, textos datilografados, manuscritos etc. A subsérie "administrativa" é uma seção composta por documentos que apresentam o timbre do CBA e que respondem pela entidade como um todo. "Núcleos", por sua vez, se refere ao material produzido por setores estaduais e municipais, além dos núcleos internacionais de Paris e Estocolmo. A segunda série ("presos políticos") agrupa documentos de casos referentes à repressão que incorreram em prisão, tortura, morte, desaparecimento e exílio, sendo dividida em quatro subseções: "históricos", "denúncias", "regime carcerário" e "produção do preso". A terceira série ("manifestações de apoio") é composta por documentos em prol da defesa dos direitos humanos e está distribuída em: "entidades, grupos, comitês", "categoria profissional" e "sociedade civil". Por fim, a quarta série ("eventos") apresenta a documentação sobre os encontros promovidos pelo CBA, individualmente ou em cooperação com outros grupos envolvidos na questão dos direitos humanos. Divide-se em: "encontros, manifestações, reuniões e outros" e "congressos" que acontecerem em 1978 e 1979.

O fundo documental do CBA não tem o intuito de ser um acervo de documentos ligados à história da literatura ou exclusivamente composto por textos literários. Apesar disso, no processo de seleção, organização e montagem do fundo, há um item parcialmente reservado à "produção de caráter literário": a pasta 042.

SÉRIE II: PRESOS POLÍTICOS: Subsérie: Produção do Preso. Item: Documentação de presos. Documentos de caráter mais confidencial, como correspondência entre casais de presos, dos presos para seus familiares, cartões de Natal, de felicitações, bem como produção de caráter literário: poesias, prosas etc. Subitem: Correspondência; Subitem: Produção Literária. [CBA, pasta 042] (AEL-DIGIT@L [INVENTÁRIO, s.d.]: 17-18)

Em relação à poesia, a pasta apresenta duas compilações de inéditos escritos dentro da prisão: o volume Ecos do Cárcere, de José Emilson Ribeiro da Silva (fig. 2), e 23 poemas numerados e não-intitulados de Pinheiro Salles (fig. 3 [fragmento do poema "A prisão"]). 

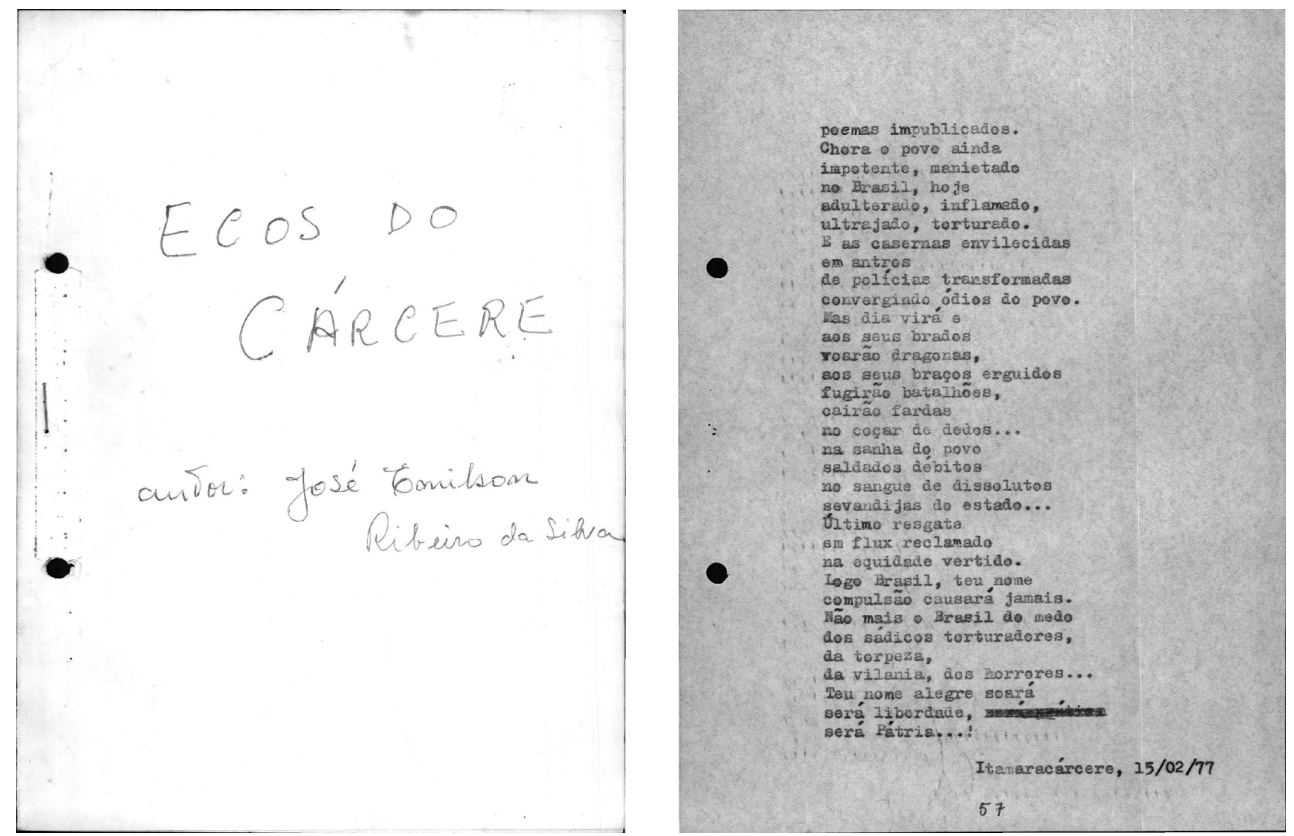

Fig. 2 e 3 - Poemas disponíveis nos fundos documentais do CBA (pasta 042).

Além dessas duas coletâneas, a pasta apresenta ainda alguns poemas esparsos, datilografados ou manuscritos, incluindo

[...] uma correspondência de Marcelo Mário de Mello a Ruth Escobar, [na qual o autor envia] dois poemas datilografados ("Não devem sofrer" e "A argila e a pedra") com pedido de edição de seu livro de poesia; três poemas datiloscritos de Aybirê Ferreira de Sá ("Apelo à mãe", "Noites no calabouço" e "A saudade do prisioneiro", 1973) que, posteriormente, foram editados pelo autor no livro Versos reprimidos: antes e depois da Anistia; um poema ("Dia") de Maria Cristina Ferreira de Oliveira; dois poemas anônimos, "Meu coração ateu" (poema/diário de 4 páginas manuscritas) e "Na cela" (datiloscrito); por fim, um poema inacabado ("Do ventre fecundo") de Pedro Tierra. Ao ser justaposta a "documentos de caráter mais confidencial" como as cartas, a "produção literária" se inscreve, no arquivo, a partir de um jogo tenso e contraditório entre aquilo que acopla e reúne os materiais dispersos no mesmo espaço e aquilo que aparta, desde uma linha divisória invisível, o confidencial e o poético. Essa divisão é escutada por nós como uma tensão entre o privado e o coletivo. (Ribeiro 2020a: 191)

Ainda que haja uma pasta destinada à produção dos presos, uma leitura das outras seções desse corpo documental atesta a proliferação de poemas ligados à campanha pela anistia, conjunto de escritos que pode ser encontrado no decurso das muitas outras pastas. 


\section{A poesia circunstanciada à campanha pela "anistia ampla, geral e irrestrita"}

$\mathrm{Na}$ conjuntura que deu base à formação do Comitê Brasileiro pela Anistia, a produção artístico-cultural foi extensivamente usada como estratégia para disseminar o ideário da luta pela anistia em todo o território nacional, fato reconhecível, por exemplo, no musical Revolta da Chibata, do Grupo Mambembe (1979), que entoava o lema da luta pela anistia em uma de suas canções; ${ }^{4}$ no espetáculo Revista do Henfil, montado pelo Teatro Ruth Escobar (1979); no samba "O bêbado e o equilibrista", composto por João Bosco e Aldir Blanc (1979) - e gravado por Elis Regina no álbum Essa Mulher; e em muitos trabalhos do cartunista Henfil.

Ocupando um lugar relevante entre os objetos estéticos (Pêcheux 2011a), a poesia serviu ora como (1) meio de didatização e propagação dos motes pró-anistia, ora como (2) forma de denúncia, testemunho e rememoração dos eventos traumáticos.

(1) Alguns poemas ou folhetos foram escritos, mimeografados e distribuídos com o propósito de difundir as pautas da campanha pela anistia. Considerando sua função didática e propagandística, não era incomum que essa poesia de circunstância textualizasse a palavra "anistia" e outros elementos associados a seus efeitos de sentido dominantes, como a palavra "liberdade" ou o próprio lema do movimento.

No folheto "Anistia ampla, geral e irrestrita: uma conquista do povo", por exemplo, o ex-preso político Aybirê Ferreira de Sá convoca a classe operária para integrar o novo núcleo do CBA. Em cada quadra, prevalece uma única rima externa entre o segundo e o quarto versos, em concordância com a composição e a sonoridade típicas da poesia popular, como é possível ler no recorte a seguir:

\section{Folheto do C.B.A.}

De: Aybirê Ferreira de Sá.

Companheiros operários

Queremos lhes comunicar

Foi fundado em Recife

Mais um novo C.B.A.

E para melhor entendermos

O que isso vai significar

Vamos contar em alguns versos

O que vem a ser o C.B.A.

É que no Brasil em que vivemos

Desde 64 para cá

Existe uma ditadura

Que ao povo quer esmagar. 


\author{
Acontece que o povo \\ Jamais vai se entregar \\ Por isso luta e se organiza \\ Para a ditadura derrubar. \\ Acontece que nesta luta \\ Muita gente já tombou \\ Outros foram presos e torturados \\ E até hoje a reação não os soltou. \\ É por isso que fundamos \\ O nosso C.B.A. \\ Para lutar pela justiça \\ E nossos presos libertar. \\ [...] \\ Recife, 27 de abril de 1979.
}

Divulgação de: Comitê Brasileiro pela Anistia de Pernambuco.

(AEL-DIGIT@L [pasta 004 - Núcleos (PE), 1979]: 7)

Apesar de se referir ao "povo" e às "massas camponesas", o leitor é identificado como "companheiros operários", interpelação retomada na seguinte estrofe: "Para isso apelamos/ Aos que mais sabem pelejar/ Que a classe operária/ Venha apoiar o C.B.A.”. A "simplicidade" com a qual o poeta seleciona e combina as palavras remete a um efeito de transparência da linguagem e a uma suposta espontaneidade da criação artística. Tais fatores, todavia, são construções discursivas sustentadas por um imaginário de língua, cultura, literatura e leitor. Sendo assim, não é trivial que essa poesia de natureza políticopanfletária privilegie uma dicção poética e uma estrutura semelhantes à da literatura de cordel. $^{5}$

(2) Os textos poéticos usados como forma de denúncia, testemunho e rememoração, por sua vez, advêm de diferentes tradições e condições de produção.

O vínculo entre essa literatura de teor testemunhal e a luta pela anistia nem sempre é explícito, mas necessariamente sobredeterminado pela forma como os escritos são selecionados, classificados e dispostos na tessitura do arquivo, tanto nos fundos documentais quanto na composição material (Lagazzi 2019) dos livros, incluindo seções "paratextuais" como capa, quarta capa, prefácio e dedicatória. Distinguindo-se de uma mera somatória de elementos, o termo "composição" permitiria dar consequências ao dispositivo da AD materialista em sua potência descritiva. Esse termo deixa entrever não apenas como diferentes materialidades significantes se imbricam, mas também como 
elas localizam marcas diversas de um mesmo processo discursivo, abrindo espaço para o imprevisto na deriva dos sentidos.

(...) não se trata de buscar complementaridade entre as diversas materialidades, mas de considerar, a partir da pergunta da análise, os diferentes modos de estruturação do material em sua imbricação, com a especificidade desse conjunto formado, relacionando uma materialidade às outras pela contradição, o que permite o movimento de substituições e encadeamentos, no contrapondo do conjunto. (Lagazzi 2019: 297)

Um caso exemplar é a reprodução fac-similar de poemas atribuídos a guerrilheiros mortos (Primeiras Cantigas do Araguaia) (fig.4).

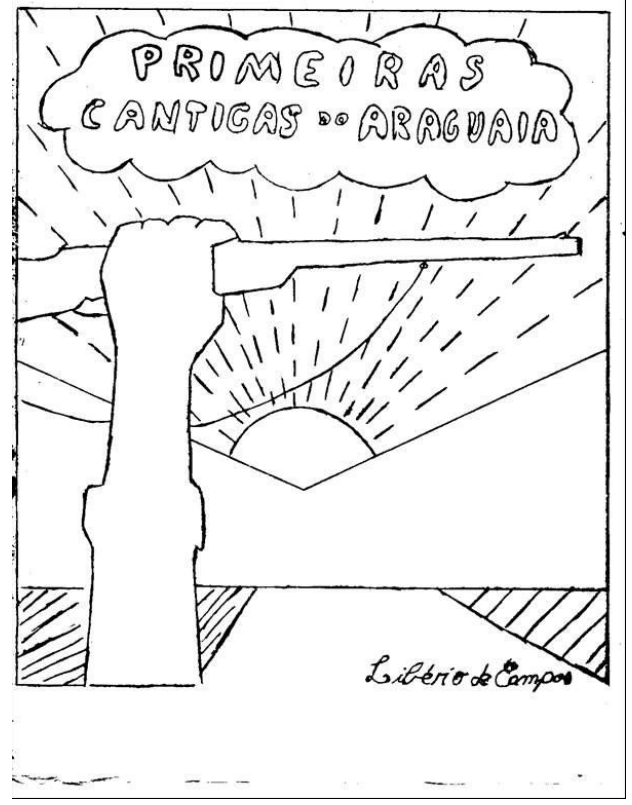

Silhuetas

1. cidade grande

à sombra

dos arranha-cóus

plantam-se

2. campo

no tempo

sempre-gerúndio

- latifúndio

escravizando

1 ǵvas

guas homene

Fig. 4 - Capa e poema de Primeiras Cantigas do Araguaia, de Libério de Campos.

Disponível em: <http://www.docvirt.com/docreader.net/bibliotbnm/20986>. Acesso em 10 set. 2021.

O CBA e os familiares de mortos e desaparecidos justificaram a impressão do livreto pelo valor afetivo e histórico (e não literário), caracterizando-a como um resgate da memória. 
Estas poesias foram feitas provavelmente pelos guerrilheiros do Araguaia. Sua primeira publicação parcial se deu em 1979 no jornal "Resistência", do Pará [...]. Os pais de uma das guerrilheiras, quando estiveram na região procurando obter informações do paradeiro da filha, mantiveram contato com o Jornal Resistência e conseguiram trazer uma cópia completa das poesias.

Quem as lê percebe que, de fato, foram feitas por pessoas muito íntimas da guerrilha. 0 prefácio original - "Cantar é Preciso", escrito todo no plural, contradiz a assinatura de um único autor no final do mesmo. "Libério de Campos", pode ser, inclusive, uma alusão dos autores aos objetivos de sua luta - "Liberdade-Camponeses". No próprio prefácio o seu início diz claramente "há dois anos, guerrilheiros no Araguaia" - situando os autores. Enfim, a própria maneira que chegou, enviada pelo correio para "O Estado do Pará", sem maiores explicações, sem remetentes, sem nada, reforça ainda mais nossa hipótese. [...] Estas poesias são de imenso valor para nós. Primeiro por ser um resto de vida, do coração de nossos entes queridos, perdidos de forma tão bárbara na Guerrilha. Depois, pelo seu valor histórico, pois constituem sem dúvida um material precioso para o estudo da guerrilha, das aspirações dos guerrilheiros, de como encaravam a luta.

Sendo assim, decidimos publicá-las, pois sabemos da nossa responsabilidade na tarefa de resgatar a memória dos nossos filhos, pais, irmãos, maridos, que participaram da guerrilha do Araguaia. Mantivemos na íntegra o caderno, conforme chegou-nos às mãos. O desenho de capa é também do original enviado ao "O Estado do Pará".

FAMILIARES DE MORTOS E DESAPARECIDOS NA GUERRILHA DO ARAGUAIA. Julho de 1980. (Campos 1980: 4-5)

Os aspectos temáticos, formais e composicionais desta segunda tendência são bastante heterogêneos. Contudo, é possível notar um predomínio de assuntos relacionados à separação amorosa, ao luto, ao cotidiano das prisões, às rememorações da vida militante e clandestina. Não faltam poemas sobre graves violações de direitos humanos, que enodam experiências pessoais e históricas, como o confinamento, a tortura institucionalizada e o desaparecimento forçado de pessoas (Ribeiro 2020b).

Sem dúvida, a poesia dos ex-presos políticos compõe o grupo mais expressivo entre os poemas de "teor testemunhal" disponíveis no arquivo da anistia, seja porque sua produção e circulação foram intensificadas por acontecimentos específicos (como a greve de fome nacional pela anistia), seja porque muitos dos poetas vieram a publicar depois da promulgação da lei da anistia também no ano de 1979. ${ }^{6}$ Não por acaso, os dois livros de poesia incluídos na lista de Flamarion Maués (2011) - "Livros na campanha pela anistia" - são obras de autores que começaram a escrever na prisão sob condições análogas: Inventário de Cicatrizes, de Alex Polari (1978), e Poemas do Povo da Noite ([1975] 1979), de Pedro Tierra. 
Inventário de cicatrizes, de Alex Polari. São Paulo; Rio de Janeiro: Global; Teatro Ruth Escobar; Comitê Brasileiro pela Anistia-RJ, 1978. Descreve situações vividas pelo autor na prisão como preso político, entre as quais as torturas de que foi vítima.

$[\ldots]$

Poemas do povo da noite. São Paulo: Editorial Livramento, 1979. Livro de poemas de Pedro Tierra, pseudônimo de Hamilton Pereira da Silva, escrito durante o período em que o autor esteve preso, entre 1972 e 1977. Seus poemas descrevem os duros momentos passados pelos presos políticos, as torturas, a morte de muitos deles e a luta pela vida dos que resistiram às sevícias. A primeira edição do livro, artesanal e não comercial, ocorreu em 1975. A primeira edição comercial foi na Espanha, pela editora Sígueme, de Salamanca, de 1978. A $3^{a}$ edição ampliada do livro foi lançada, em 2010, pela Publisher em coedição com a Editora Fundação Perseu Abramo. (Maués 2011: 265).

O livro de Alex Polari citado por Maués é um exemplo de produção poética que circulou, ao mesmo tempo, como meio de divulgação da luta pela anistia e como testemunho das perdas pessoais e coletivas causadas pela repressão política.

Esse livro é inseparável da luta pela anistia que ocorria dentro e fora do presídio Frei Caneca. Trata-se de uma seleção de 53 poemas escritos pelo autor desde o começo da década de 1970 e em diferentes cárceres da ditadura.

Como ocorreu com outros presos, alguns de seus poemas atravessaram clandestinamente os muros da prisão, sendo divulgados em manifestações, passeatas e jornais de resistência do Brasil e do exterior. Para Wilberth Salgueiro (2011), antes mesmo de abrirmos o livro, já podemos depreender alguns direcionamentos de leitura, designando-o como obra "testemunhal", "engajada", de "militância", de "denúncia" etc. Isso ocorre devido à imbricação das materialidades significantes (Lagazzi 2019) que o compõem: as imagens da capa, o nome das instituições contrárias à ditadura que fomentaram a publicação e, na quarta capa, a minibiografia política do autor, assim como a subscrição (em caixa alta) "PRODUTO DA VENDA DESTE LIVRO EM BENEFÍCIO DO COMITÊ BRASILEIRO PELA ANISTIA".

Além disso, parte significativa de seu material de lançamento está localizada no acervo do CBA-RJ. Para o movimento, a poesia era compreendida como uma "parte específica" de uma "demanda política geral". Por discorrer sobre torturas, morte e desaparecimento de militantes, a sua poesia foi designada como um "difícil testemunho daquela geração que se lançou na luta contra a ditadura militar" (AEL-DIGIT@L [Pasta 005 - Núcleos (RJ), 1978]: 96).

Nesse livro, encontra-se um dos poemas de cárcere mais conhecidos: "Canção para 'Paulo' (A Stuart Angel)”. O poeta - ainda preso - alude ao episódio de captura, tortura, execução e ocultação do corpo do militante. Torturado ao seu lado, ele foi também uma testemunha do suplício. Amarrado à traseira de um carro, o desaparecido foi arrastado no pátio da Base Aérea do Galeão e forçado a respirar os gases do escapamento. Uma das 
suspeitas em torno de seu desaparecimento é a de que seu corpo teria sido lançado de helicóptero na escuridão do mar, num ponto indefinido da Restinga da Marambaia:

\section{CANÇÃO PARA “PAULO” (A STUART ANGEL)}

Eles costuraram tua boca

com o silêncio

e trespassaram teu corpo

com uma corrente.

Eles te arrastaram em um carro

e te encheram de gazes,

eles cobriram teus gritos

com chacotas.

Um vento gelado soprava lá fora

e os gemidos tinham a cadência

dos passos dos sentinelas no pátio.

Nele, os sentimentos não tinham eco

nele, as baionetas eram de aço

nele, os sentimentos e as baionetas se calaram.

Um sentido totalmente diferente de existir

se descobre ali,

naquela sala.

Um sentido totalmente diferente de morrer

se morre ali,

naquela vala.

Eles queimaram nossa carne com os fios

e ligaram nosso destino à mesma eletricidade.

Igualmente vimos nossos rostos invertidos

e eu testemunhei quando levaram teu corpo

envolto em um tapete.

Então houve o percurso sem volta

houve a chuva que não molhou

a noite que não era escura

o tempo que não era tempo

o amor que não era mais amor

a coisa que não era mais coisa nenhuma. 


\begin{abstract}
Entregue a perplexidades como estas, meus cabelos foram se embranquecendo e os dias foram se passando.
\end{abstract}

(Polari 1978: 36)

Tais livros, vistos como um todo (ainda que sejam a compilação de poemas escritos em diferentes condições de produção), combinam as tendências acima destacadas, servindo, simultaneamente, como denúncia da violência ditatorial e propaganda do movimento.

Eventualmente, o CBA recorria a poemas produzidos em outras conjunturas, construindo, assim, uma rede de filiação para embasar os motes da luta pela anistia em sua atualidade. Isso ocorre, por exemplo, com o "Poema de março de 45", de Carlos Drummond de Andrade. Ele foi escrito na época em que outra anistia havia sido sancionada (no final do primeiro governo de Getúlio Vargas). Em uma carta de 10 de maio de 1978, o poeta anexa a versão fac-símile do poema, comparando os dois contextos e manifestando seu apoio à nova campanha pela anistia. ${ }^{7}$

Apesar de haver diferenças entre os dois projetos de anistia, essa comparação forja uma espécie de elo entre tempos diversos, conferindo um efeito de continuidade e de longevidade a uma campanha que, de fato, se consolidou apenas a partir da segunda metade da década de 1970. Ainda que pudesse ressignificar o passado de média ou longa duração, a campanha cessaria em poucos anos. Após a promulgação da lei da anistia, os perseguidos pela ditadura publicariam seus livros de poesia, dando forma a um quadro literário específico e circunstanciado ao momento da transição política.

No artigo "Um eu encoberto", publicado no Jornal do Brasil, a crítica literária Heloísa Buarque de Hollanda (1981: 10) deu relevo à disseminação de um "quase gênero" que nascia sob o signo da abertura: a literatura dos exilados e dos presos políticos recémanistiados. Referindo-se, particularmente, aos "agentes, sujeitos e [...] objetos de um segmento da história pós-64, a luta armada", essa produção apresentava algumas diferenças em relação a gêneros narrativos tradicionais, como autobiografias e relatos históricos.

Para a autora, a prosa e a poesia dos presos e exilados remetiam, sobretudo, à ideia de um "depoimento testemunhal", que tinha como principais características a pouca informação original sobre os acontecimentos dos últimos anos e a busca de uma articulação do político com o pessoal. Em texto posterior, escrito um ano depois, Hollanda dirigiu novamente o olhar a essa literatura específica e circunstanciada ao momento, designando-a como uma tentativa de resgate da história perdida ou silenciada. Em suas palavras,

[...] o período pós-78, com a animação sugerida pela queda da censura prévia e pelo projeto de abertura, inaugurou uma safra literária bastante específica e circunstanciada ao momento. 
Foi o que observei exatamente há um ano, neste mesmo JB, sob o título genérico de "literatura de exílio e poesia na prisão". Os anos 79-80 foram marcados pelo extremo interesse em torno do relato de próprio punho daqueles personagens que, direta ou indiretamente, participaram dos movimentos de luta armada ou da militância política mais efetiva e que agora, de volta, procuravam resgatar partes de uma história perdida ou silenciada. (Hollanda 1982: 10 [Caderno B])

Segundo esse ponto de vista, a poesia dos ex-presos poderia, em hipótese, ser reconhecida como parte do boom das autobiografias dos militantes políticos. Uma revisão da literatura crítica mostra a existência de muitos estudos acadêmicos sobre essas produções autobiográficas em prosa, sobretudo a partir de um viés sociológico ou estético (Lasch 2012). Na contracorrente, são raras quaisquer menções à poesia da anistia e aos poetas anistiados (mesmo em estudos mais panorâmicos) e praticamente inexistem trabalhos sistemáticos de recensão, periodização, descrição, interpretação e divulgação da poesia disponível no arquivo da anistia. Diante de tal lacuna, publicamos, anteriormente, uma pesquisa sobre a poesia dos ex-presos políticos, considerando-a como uma série extensa e relativamente independente das autobiografias em prosa, inclusive em termos de periodização. Listamos uma amostragem significativa de elaborações poéticas publicadas desde o final da década de 1970 até a atualidade e as distribuímos em três seções: a) "as obras editadas"; b) "a poesia do cárcere e a imprensa de resistência"; e c) "a poesia dos presos políticos no arquivo" (Ribeiro 2020a). Nos três casos, a relação entre poesia e anistia figurou como um problema fundamental a ser pesquisado. Além da recensão em fundos documentais digitais, a pesquisa nos levou também aos livros editados, uma vez que: fomentaram ou foram fomentados pelo CBA; estiveram circunstanciados aos acontecimentos em questão (como as greves de fome pela anistia); e/ou tiveram sua circulação associada à lei da anistia.

Salvo exceção, quando assumia a forma "unitária" de um livro, de brochura caseira ou impresso em gráficas pequenas, essa produção não se inscrevia no circuito tradicional "autor-editora-livraria-público" (Jutgla 2015). Sendo assim, parte fundamental do nosso arquivo é composta por livros de poesia situados entre os anos de 1978 e 1981 e diretamente relacionados à luta pela anistia. Com base em um trabalho prévio de reunião desse material, selecionamos seis títulos a serem descritos e interpretados em pesquisas futuras, além dos dois mencionados anteriormente: ${ }^{9}$

- $\quad$ Poemas do cárcere e da liberdade, de Oswald Barroso (1979);

- Poemas da greve de fome \& 10 textos de Itamaracá, de Marcelo Mário de Melo (1979);

- $\quad$ Os quatro pés da mesa posta (Poesia-Prisão-Política), de Marcelo Mário de Melo (1980);

- Camarim de prisioneiro, de Alex Polari (1980);

- Poesia na prisão, coletânea organizada por Neila Tavares (1980);

- Versos reprimidos: antes e depois da anistia, de Aybirê Ferreira de Sá (1981). 
Em síntese, traçamos uma via para a pesquisa da poesia no arquivo da anistia a partir da pesquisa em três campos: o fundo do CBA; outros acervos digitais; e os livros de poesia. O trilhar por esses documentos possibilita questionar a leitura do material a partir de um movimento pendular: de um lado, há um confronto com as diferentes formas de "saturação" do arquivo (Robin 2016) e, de outro, o confronto com traços poéticos singulares, as diferentes dicções e projetos estéticos de cada escritor, livro, poema etc.

Diante desse embate entre a regularidade do arquivo e a singularidade do trabalho poético sobre a língua, há uma série de questões que constituem a base para estudos futuros: em que medida e de que forma os objetos poéticos disponíveis no arquivo textualizam acontecimentos históricos e discursivos ligados à primeira fase da luta pela anistia no Brasil? Como o movimento pró-anistia produziu, selecionou, enquadrou, organizou e colocou em circulação o material poético disperso nos fundos documentais pesquisados? De que modo o par anistia/liberdade foi significado nos poemas e em enunciados do CBA? Quais são as tendências e as regularidades temáticas, formais e composicionais dessa poesia, antes e depois da promulgação da lei da anistia (lei 6.683/1979)? Que efeitos de sentidos, antes interditados e silenciados, entram em circulação a partir desse "arquivo poético"?

NOTAS

* Thales de Medeiros Ribeiro: Graduado em Letras pelo Centro Universitário de Itajubá (FEPI). Mestre e doutor em Linguística pelo Instituto de Estudos da Linguagem (IEL-Unicamp). Pós-doutorando na Faculdade de Filosofia, Ciências e Letras de Ribeirão Preto (FFCLRP-USP), sob a supervisão da Profa. Dra. Lucília Maria Abrahão e Sousa. Atualmente, pesquisa o tema "poesia e acontecimento no arquivo da anistia". É Membro do Laboratório Discursivo El@dis e do grupo de pesquisa “Discurso e memória: movimentos do sujeito". Trabalha, principalmente, com as seguintes áreas: psicanálise, análise do discurso, literatura brasileira e história das ideias linguísticas. Juntamente com o Prof. Dr. Lauro Baldini, coordena o grupo de pesquisa PsiPoliS (Psicanálise, Política, Significante) do IEL-Unicamp. 
${ }^{1}$ No período que corresponde à primeira fase da luta pela anistia, este termo era significado como um sinônimo de "liberdade" Em "Mutações do conceito de anistia na justiça de transição brasileira", Paulo Abrão e Marcelo Torelly argumentam que a significação política e jurídica da palavra "anistia" na história brasileira leva ao contexto de disputa entre o regime e movimentos de resistência: "A palavra de ordem do movimento social é a 'anistia ampla, geral e irrestrita', referindo-se a todos os 'crimes' políticos praticados na resistência contra o regime. Esta [...] primeira fase da luta pela anistia caracteriza, portanto, a anistia 'enquanto liberdade'. A luta social buscou o resgate das liberdades públicas: civis e políticas." Posteriormente, a palavra "anistia" seria caracterizada pelos pares "reparação e memória" e "verdade e justiça" (Abrão/Torelly 2012: n.p.).

${ }^{2}$ Sem dúvida, o MFPA exerceu um papel crucial na consolidação e na unificação da luta pela democracia. Desde a fundação do movimento, sua porta-voz defendia uma "anistia ampla e geral a todos aqueles que foram atingidos pelos atos de exceção" (Zerbini [1975] 1979: 27).

${ }^{3} \mathrm{Um}$ fragmento desse escrito aparece no livro Poesia na prisão: textos colhidos e selecionados por Neila Tavares. Há outros poemas dessa autora na coletânea em questão.

${ }^{4}$ Trata-se do "Canto de alegria”, de Ricardo Faria (1979: 13): “Leva a treva, a morte, o medo/ todo esse tormento (lento)/ Leva a espera, a fria cela/ dos servos do tempo (lento)/ leva nessa leva toda essa agonia/ traz o manto santo, o canto de alegria/ num só coro a gente grita:/ Anistia (ampla, geral, irrestrita: anistia)". As letras da peça estão disponíveis em A revolta da chibata: uma história brasileira (baseado no livro A Revolta da Chibata, de Edmar Morel), promovido e produzido pelo Centro Mineiro de Cultura Popular (CMCP): <http://www.docvirt.com/docreader.net/bibliotbnm/5595. Acesso em 10 set. 2021.

${ }^{5}$ Cf., também, "A luta pela anistia", folheto anônimo e sem data, impresso pelo núcleo do Rio Grande do Norte do CBA (AEL-DIGIT@L, [pasta 004 - Núcleos, s.d.]: 13-27); e "O homem que fugiu com medo da anistia de Figueiredo", folheto mimeografado e assinado pelo pseudônimo "Marcus" (AEL-DIGIT@L, [pasta 017 - Presos Políticos/Históricos, 1979]: 165-171).

${ }^{6}$ A propósito desses acontecimentos, cf. o livro Fome de Liberdade: a luta dos presos políticos pela anistia, de Perly Cipriano e Gilney Viana (1992).

7 "Atendendo à solicitação de sua carta, tenho o prazer de enviar-lhe junto um xerox do meu poema sobre anistia, publicado pelo Diário Carioca, [...] em 29 de março de 1945. Hoje, como naquele ano, sou favorável a essa medida pacificadora da sociedade brasileira. Cordialmente, Carlos Drummond de Andrade" (AEL-DIGIT@L [Pasta 050 - Manifestações de apoio/Categoria profissional, 1978]: 77).

${ }^{8}$ No quadro da AD, Orlandi (2007) analisou a avalanche de produções autobiográficas como fato de linguagem. Para ela, a etiqueta "ficção política", inscrita na capa das narrativas em prosa, indicava uma relação determinada entre a escrita e o silêncio, entre o sujeito e o poder-dizer. A difusa circulação desses textos literários apontava também para o funcionamento de certos processos de identificação dos sujeitos sob o regime autoritário: a obrigação de se separar dos outros (na prisão ou no exílio) produziu um efeito de retorno do sujeito sobre a própria identidade, nublando os limites entre o "eu-político" e o "eu-pessoal".

${ }^{9}$ Não ignoramos que alguns poemas, inscritos nas mesmas condições de produção, foram publicados mais de três décadas após a sanção da lei da anistia, como: a) Poemas (quebrados) do cárcere, de Gilney Viana (2011); b) Eterno amanhã: poemas da prisão, de André Borges (2011); e c) Cárceres da memória (1970-1980), de Chico de Assis (2017). 


\section{BIBLIOGRAFIA}

AEL DIGIT@L (Arquivo Edgard Leurenroth-Unicamp). Fundo documental do comitê brasileiro pela anistia. Pastas. Disponível em: <https://www.ael.ifch.unicamp.br/aeldigital/comit\%C3\%AA-brasileiro-pela-anistia-cba>. Acesso em 11 fev. 2021.

Abrão, Paulo/ Torelly, Marcelo D. (2012), "Mutações do conceito de anistia Justiça de Transição brasileira", Revista de Direito Brasileira, CONPEDI, n. 3, p. 357-379.

Assis, Chico de (2017), Cárceres da memória: 1970-1980. Recife, Ed. do Autor.

Barroso, Oswald (1979), Poemas do cárcere e da liberdade. Fortaleza, Edições Multirões do Povo [Série Poesia].

Borges, André (2001), Eterno amanhã: poemas da prisão. Rio de Janeiro, Debret.

BNM DIGIT@L (Brasil: Nunca Mais Digit@l). Uma iniciativa histórica. Disponível em: <http://bnmdigital.mpf.mp.br/pt-br/>. Acesso em 15 nov. 2021.

BRASIL: NUNCA MAIS. Prefácio de D. Paulo Evaristo, Cardeal Arns. Petrópolis: Vozes, 1985. Disponível em: <http://www.docvirt.com/docreader.net/bibliotbnm/445> . Acesso 10 set. 2021.

Campos, Libério de (1980), Primeiras cantigas do Araguaia. Homenagem ao $2^{\circ}$ aniversário da resistência armada das forças guerrilheiras do Araguaia. Familiares de Mortos e Desaparecidos na Guerrilha do Araguaia/Comitê Brasileiro pela Anistia. Impressão: Centro Minério de Cultura Popular.

CBA/PRODUÇÃO DE PRESOS POLÍTICOS. Pasta 042 (Presos políticos/ produção do preso/ documentação) dos Fundos documentais do COMITÊ BRASILEIRO PELA ANISTIA. AEL Digit@l (Arquivo Edgard Leurenroth-Unicamp). 223 p.

Di Nizzo, Patricia Leal (2019), Um ensaio sobre o cinismo: distorções e reapropriações performativas nas práticas discursivas contemporâneas. Tese (Doutorado em Linguística). Campinas: Unicamp.

Figueiredo, Eurídice (2017), A literatura como arquivo da ditadura brasileira. Rio de Janeiro, 7Letras.

Hollanda, Heloísa Buarque de (1981), “Um eu encoberto”. Jornal do Brasil, p. 10.

-- (1982), “A luta dos sufocados e o prazer dos retornados”. Jornal do Brasil, p. 10.

Indursky, Freda (2014), "Uma análise discursiva da lei da anistia e seus efeitos de sentido", in SIGMUND FREUD ASSOCIAÇÃO PSICANALíTICA (Org.), Clínicas do testemunho: reparação psíquica e construção de memórias. Porto Alegre, Criação Humana: 213238.

Jutgla, Cristiano Augusto da Silva (2015), "Poesia de resistência e a luta por Direitos Humanos". Via Atlântica (USP), v. 28, p. 395-412.

Lagazzi, Suzy (2019), “Entre o amarelo e o azul: a história de um percurso". Línguas e instrumentos linguísticos, n. 44, p. 286-311.

Lasch, Markus (2012), "Em câmara lenta: representações do trauma no romance de Renato Tapajós”. Remate de Males, v. 30, n. 2, p. 277-291. 
Maués, Flamarion (2011), "Livros na campanha pela anistia”. in Perseu: História, Memória e Política. São Paulo, Fundação Perseu Abramo: 257-277.

-- (2005), “Ter simplesmente este livro nas mãos é já um desafio”: livros de oposição no regime militar, um estudo de caso. Em questão, UFRGS, v. 11, n. 2, p. 259-279.

Melo, Marcelo Mário (1979), Poemas da greve de fome \& 10 textos de Itamaracá. s/l. Disponível em: <http://www.docvirt.com/docreader.net/BibliotBNM/20939>. Acesso 11 fev. 2021.

-- (1980), Os quatro pés da mesa posta: Poesia-Prisão-Política. Itamaracá, Edições Pirata. Orlandi, Eni (2007), As formas do silêncio: no movimento dos sentidos. Campinas, Unicamp. Pêcheux, Michel (2010), "Ler o arquivo hoje", in Orlandi, Eni (Org.), Gestos de leitura: da história no discurso. Campinas, Unicamp: 49-60.

-- (2011a), “Ideologia: aprisionamento ou campo paradoxal?”, in Pêcheux, Michel, Análise de discurso: textos selecionados por Eni Orlandi. Campinas, Pontes: 107-120.

-- (2011b), "Metáfora e interdiscurso", in Pêcheux, Michel, Análise de discurso: textos selecionados por Eni Orlandi. Campinas, Pontes: 151-162.

-- (2012), O discurso: estrutura ou acontecimento?. Campinas, Pontes.

Polari, Alex (1978), Inventário de Cicatrizes. Rio de Janeiro/São Paulo, CBA/Ruth Escobar/ Global Editora.

-- (1980), Camarim de prisioneiro. São Paulo, Global Editora.

Rezende, José Roberto Gonçalves (1992), “É penoso”. In: CIPRIANO, Perly; VIANA, Gilney. Fome de liberdade: a luta dos presos políticos pela anistia. Vitória: s./n.,. p. 254.

Ribeiro, Thales de Medeiros (2020a), "A poesia dos presos políticos”. Travessias, Cascavel, v. 14, n. 2, p. 177-197.

-- (2020b), Literatura cinza: uma (sub)versão do luto em Inventário de cicatrizes. Tese (Doutorado em Linguística). Campinas, Unicamp.

Robin, Régine (2016), A memória saturada. Campinas, Unicamp.

Sá, Aybirê Ferreira (1981), Versos reprimidos: antes e depois da anistia. Recife, Edição do autor.

Salgueiro, Wilberth (2011), "Tortura sob deboche: uma questão de riso ou morte (Análise de "Trilogia Macabra", de Alex Polari)", in Anais do XII Congresso Internacional da Abralic. Curitiba: Abralic, v. 1. p. 1-10.

Tavares, Neila (Org.) (1980), Poesia na prisão: textos colhidos e selecionados por Neila Tavares. Porto Alegre, Proletra.

Tierra, Pedro (1979), Poemas do povo da noite. São Paulo, Livramento.

Viana, Gilney (2011), Poemas (quebrados) do cárcere. Rio de Janeiro, Garamond.

Viana, Gilney/ Cipriano, Perly (1992), Fome de liberdade: a luta dos presos políticos pela anistia. S.N.

Zerbini, Therezina Godoy (1979), Anistia: Semente da liberdade. São Paulo, S.N. 